\title{
Sex Worker Resistance in the Neoliberal Creative City: An auto/ethnography
}

\author{
Alex Tigchelaar
}

\begin{abstract}
Sex workers are subjects of intrigue in urban and creative economies. Tours of active, deteriorating, or defunct red-light districts draw thousands of tourists every year in multiple municipalities around the world. When cities celebrate significant anniversaries in their histories, local sex worker narratives are often included in arts-based public offerings. When sex workers take up urban space in their day-to-day lives, however, they are criminalised. Urban developers often view sex workers as existing serviceably only as legend. A history of sex work will add allure to an up-and-coming neighbourhood, lending purpose to its reformation into a more appropriately productive space, but the material presence of sex workers in these neighbourhoods is seen as a threat to community wellbeing and property values. This paper considers how sex workers, continuously displaced from environments they have carved out as workspaces, may use the arts to draw attention to these ongoing contradictions. It investigates how sex workers may make visible the idiosyncratic state of providing vitality to a city's history while simultaneously being excluded from its living present. Most critically, it suggests ways in which sex workers may encourage those involved as producers and consumers of neoliberal urban revitalisation projects to connect these often fatal paradoxes to the laws that criminalise their labour.
\end{abstract}

Keywords: sex work, criminalisation, neoliberalism, creative space, Nuit Blanche

Suggested citation: A Tigchelaar, 'Sex Worker Resistance in the Neoliberal Creative City: An auto/ethnography', Anti-Trafficking Review, issue 12, 2019, pp. 15-36, www.antitraffickingreview.org

This is an open-access article distributed under the terms of the Creative Commons Attribution License (CC-BY). Under the CC-BY license, the public is free to share, adapt, and make commercial use of the work. Users must always give proper attribution to the authors and the Anti-Trafficking Review. 
How are ideas of 'creativity' produced, consumed, mutated and/ or contested and resisted by different actors at different scales within specific urban contexts, producing multiple ways that 'creativity' is understood within cities, and what are the implications of this?

Thomas Borén and Craig Young

\section{Introduction}

In the fall of 2016, I met with the Russian collective Chto Delat (What is to be done?) to discuss a collaboration for Toronto's Nuit Blanche in September 2017. Established in 2003, Chto Delat is a dynamic group of 'artists, critics, philosophers, and writers from St. Petersburg, Moscow, and Nizhny Novgorod with the goal of merging political theory, art, and activism.' The group describes itself as 'an artistic cell and a community organiser for a variety of cultural activities intent on politicising "knowledge production." 2 Their work addresses current political struggles in Russia and their relationship to those in other countries. The collective's members work with multiple media, including video, theatre, murals, public campaigns, and talks.

Launched in Paris in 2001, Nuit Blanche is now an annually and internationally staged free citywide arts festival. Running from dusk till dawn, events include sound, projection and light installations, dance and movement performances, and imagistic contributions by local and international artists. Chto Delat had been commissioned by Toronto's Nuit Blanche to create an installation in collaboration with the American curator Nato Thompson, called 'The Monument to One Hundred Years of Revolutions.' The installation was to be a grouping of shipping containers 'producing a small village... a veritable mass-shipped revolution that unpacks into a world. ${ }^{3}$ Chto Delat would curate about half the containers featuring 'a different moment in revolutionary history ranging from the Mexican Revolution, Yugoslavia and China to May '68, Cuba, and to Zapatista.' ${ }^{4}$ The others would be curated by local artist-activists. These containers would highlight Indigenous peoples, migrant workers, sex workers, queer advocacy, and activism around the African diaspora.

1 T Borén and C Young, "Getting Creative with the "Creative City"? Towards new perspectives on creativity in urban policy', International Journal of Urban and Regional Research, vol. 37, no. 5, 2013, pp. 1799-1815, p. 1804, https://doi.org/ 10.1111/j.1468-2427.2012.01132.x.

2 Chto Delat, http://chtodelat.org.

3 N Thompson, 'Now is a time to reflect', Creative Time, n.d., http:// creativetime.org/summit/toronto-2017.

4 No author, 'Monument to the Century of Revolutions: Nuit Blanche Toronto', Just Seeds, 2017, https://justseeds.org/event/monument-to-the-century-ofrevolutions-nuit-blanche-toronto. 
Nuit Blanche organisers requested that I meet with Chto Delat because, like them, I merge activism, art, and political theory. For the most part, my creative advocacy deals with sex work, its cultural and labour history, and its criminalisation. Art has transformed my life. So has sex work. More specifically, both as an activist and a worker, I have been transformed by the many creative and radical women $I$ have met in the sex trades. Sex workers know very well what Thompson means when he argues that culture industries cannibalise the labours of artists and activists, churning out 'a new substance for a voracious and growing nest of consumers around the world. ${ }^{5}$

Sex worker participation in the world is defined both by the circumscribing laws on our own bodies and the many unnuanced representations that circulate about us in the media, legal, and arts industries. Sex workers have long argued that most people are more acquainted with mimetic representations of them than they are with real sex workers, and that these representations have more cultural and judicial authority than their own subjective experiences. ${ }^{6}$

Blockbuster arts festivals like Nuit Blanche serve as an apparatus for cities to promote their appeal on the global stage of tourism and cultural production, attracting thousands of people, both local and visiting. Toronto's inaugural Nuit Blanche took place in 2006 and since then, the event has featured 'more than 1,400 art installations created by over 4,900 artists and has generated more than $\$ 311$ million. ${ }^{7}$ As cities frequently use their sex working histories as leverage to attract cultural tourism dollars but continue to criminalise sex workers in the living present, ${ }^{8}$ a widely-attended festival like Nuit Blanche could provide an ideal opportunity to educate average citizens about these types of extractive cultural practices, along with providing first-hand accounts

$5 \mathrm{~N}$ Thompson, Seeing Power: Art and activism in the twenty-first century, Melville House, Brooklyn and London, 2015, p. 3.

6 A Tigchelaar, 'Whorientalism', Major Research Paper submitted to the Faculty of Studies in Comparative Literature and the Arts at Brock University, St. Catharines, Canada, 2016; J Doezema, Sex Slaves and Discourse Masters: The construction of trafficking, Zed Books, London, 2010; K Kampadoo, J Sanghera and B Pattanaik (eds.), Trafficking and Prostitution Reconsidered, Paradigm Publishers, Boulder and London, 2005.

7 'Nuit Blanche Toronto', Toronto.ca, retrieved 21 January 2019, https:// www.toronto.ca/business-economy/partnerships-sponsorships-donations / sponsor/major-festivals-events/nuit-blanche-toronto.

8 Cultural practices that profit off of sex worker outsider cachet simultaneously rely on the prohibition of its real presence. Montreal's 375 celebrations involved several creative offerings that took on the city's sex working history such as Vice et Vertu by Les 7 Doigts. This production not only detailed the city's sex work history but was also hosted at La Societé des Arts Technologique, which borders a formerly active sex work stroll. S Tétreault (Dir), Vice et Vertu, 2017, By Les 7 Doigts. Societé des Arts Technologique, Montréal, Québec. Performance. 
of sex workers' day-to-day lives, labour, and advocacy under the spectre of criminalisation. In this paper, I give an account of a multi-sex worker advocacy group effort to illuminate the embedded prejudices of appropriate/ appropriated rights of abode and public space in the neoliberal city. The site chosen to do this intervention was one that has itself reproduced these prejudices: Nuit Blanche.

\section{Right to the City vs. Right to Representation}

Public arts programming is intended 'to offer widespread constructive social engagement, with participants communicating, collaborating, co-creating and mutually supporting one another. ${ }^{9}$ Yet, when sex workers take up the spaces where these events are hosted in their everyday surroundings, they are viewed as undesirable and are criminalised in a variety of ways. ${ }^{10}$ A 2008 Nuit Blanche installation recreated a meta-red-light district on Toronto's Church Street, displacing real sex workers ${ }^{11}$ so that performers could imitate them. This was done with the full support of the city, Nuit Blanche's corporate funders, and law enforcement, all of whom, it goes without saying, take a much less receptive approach to real sex workers in their various institutional interactions with them.

Nuit Blanche can pay people to co-opt sex worker spaces and pretend to be sex workers for cultural entertainment. Nuit Blanche can even pay actual sex workers to do art about sex work. Yet, hiring sex workers to perform their actual services remains a crime in Canada. Foregrounding these ongoing inconsistencies in the context of the current neoliberal economy should be a priority.

9 J Harvie, Fair Play: Art, performance and neoliberalism, Palgrave MacMillan, London, 2013, p. 1.

10 A J Pitts, 'Remembering Bedford: Impacts of criminalization on street-based sex workers', Major Research Paper submitted to the Faculty of Liberal Arts and Professional Studies at York University, Toronto, Canada, 2015.

11 A Tigchelaar, 'The Creative Ass Class', in JF Prost (ed.), Heteropolis: Adaptive actions, Leonard and Bina Art Gallery, Montreal, 2014. 


\section{Canada's Sex Work Laws: Obscuring exclusions}

In my meeting with Chto Delat, I outlined one of the most pressing concerns for sex workers in Canada: the ascension in 2014 of Bill C-36, now known as The Protection of Communities and Exploited Persons Act (PCEPA). Though many people continue to believe sex work to be legal in Canada, it has never been practised fully unimpeded. Previously, sex workers were criminalised through laws that restricted their ability to work in groups and hire people to assist in their business, and in the spaces where they may conduct their business. PCEPA continues to criminalise sex workers' access to where and how they may conduct business, and the law now does so in the context of the outright criminalisation of their clients. Even though sex workers are immune to arrest and prosecution, it remains illegal to receive money for sexual services under the new law's 'material benefit' provision. Furthermore, when PCEPA was made public, clients were aligned by then Justice Minister Peter MacKay with 'perpetrators, perverts and pimps'. ${ }^{12}$ They are now, in effect, construed as sex offenders simply for engaging the services of sex workers.

As a result, clients refuse to provide the type of information that workers request to verify their credibility. ${ }^{13}$ Hundreds of North American sex workers are subject to invasive and indiscriminate cross-country raids on their workplaces in the name of locating victims of trafficking. ${ }^{14}$ During such raids, Asian and migrant women report 'violations of their basic human rights', which include 'arbitrary arrests' along with 'false allegations, and false evidence being used to keep them detained. ${ }^{15}$ While culture makers reap the rewards of producing art about sex workers, ${ }^{16}$ sex workers themselves remain endangered

12 J M Davies, 'The Criminalization of Sexual Commerce in Canada: Context and concepts for critical analysis', The Canadian Journal of Human Sexuality, vol. 24, no. 2, 2015, pp. 78-91, p. 82, https://doi.org/10.3138/cjhs.242-A9.

13 Canadian Alliance for Sex Work Law Reform, What Canada Can Learn from Sweden's Laws that Criminalize the Purchase of Sex', CASWLR, 2017.

14 See: A Woo, 'Sex-worker advocates call for end to B.C. police sting operations', The Globe and Mail, 6 July 2017, retrieved 23 December 2018, https:// www.theglobeandmail.com/news/british-columbia/sex-worker-advocates-callfor-end-to-bc-police-sting-operations/article35584381/.

15 E Lam, Bebind the Rescue: How anti-trafficking investigations and policies harm migrant sex workers, Butterfly Print, Toronto, 2018, p. 4.

${ }_{16}$ A recent example of this would be the American television series The Deuce, created and written by David Simon. Simon has made a career in journalism and television writing about criminalised populations. Another popular series he created is The Wire, which focuses largely on racialised gangs in Baltimore. The Deuce (2015). Created by David Simon. Perf. James Franco, Maggie Gyllenhaal. HBO; The Wire (2002-2008). Created by David Simon. Perf. Dominic West, Wood Harris, Idris Elba. HBO. 
by ideological and obfuscating legal policy. To describe this very particular space that we occupy, I devised the word 'viminal': victim if one does not agree to be criminalised by the state, criminal if one does not agree to be victimised by the state, ever in a liminal position.

The theme of Nuit Blanche in 2017 was 'Many Possible Futures'. For sex workers around the world, one future goal central to so much of our collective activism is the decriminalisation of our labour. With a budget of CAD 3,000 (approx. USD 2,300), CAD 500 of which was allotted to me for my role as curator, I engaged sex worker groups from Sudbury, Montreal, Toronto, and Florida that represent a broad cross-section of advocacy practices. ${ }^{17}$ We would take over one of the shipping containers and illustrate, through art, performance, and direct action, the challenges we face under criminalisation. The project was called The Viminal Space.

\section{The Activist Participants}

The groups involved in The Viminal Space engage in outreach work in different geographical, cultural, and industry locations. They were specifically chosen to highlight the multiplicity of issues faced by sex workers under criminalisation, and to illustrate how these laws impact both our 'presence' and, by extension, our futures. Bringing these groups together to participate in the project was also intended to foreground and strengthen our global friendships and solidarity.

Stella, l'amie de Maimie has been doing outreach with sex workers in Montreal since 1995. At that time, 'Public authorities were [...] debating if the opportunity was ripe to introduce and impose medical and mandatory HIV tests of sex workers.' The organisation secured its funding through 'the recommendation and approval from health officials' to do HIV prevention outreach. They used it 'to address the real needs of sex workers in the context of an HIV/AIDS pandemic.' ${ }^{18}$ Montreal sex workers were already organising, but now they had appropriate funds to do so. Making use of the 'vector of disease' model that is often employed to define sex workers and restrict their mobility, Stella, as it is more commonly known, acquired public health funding and launched what is now an award winning and internationally respected sex worker-led, sex worker-serviced organisation.

\footnotetext{
17 Street and in-call based outreach, legal aid, healthcare, government lobbying, and creative activism, such as theatre, art and magazine creation, and carceral and post-incarceration support.

18 Stella, website: http://chezstella.org.
} 


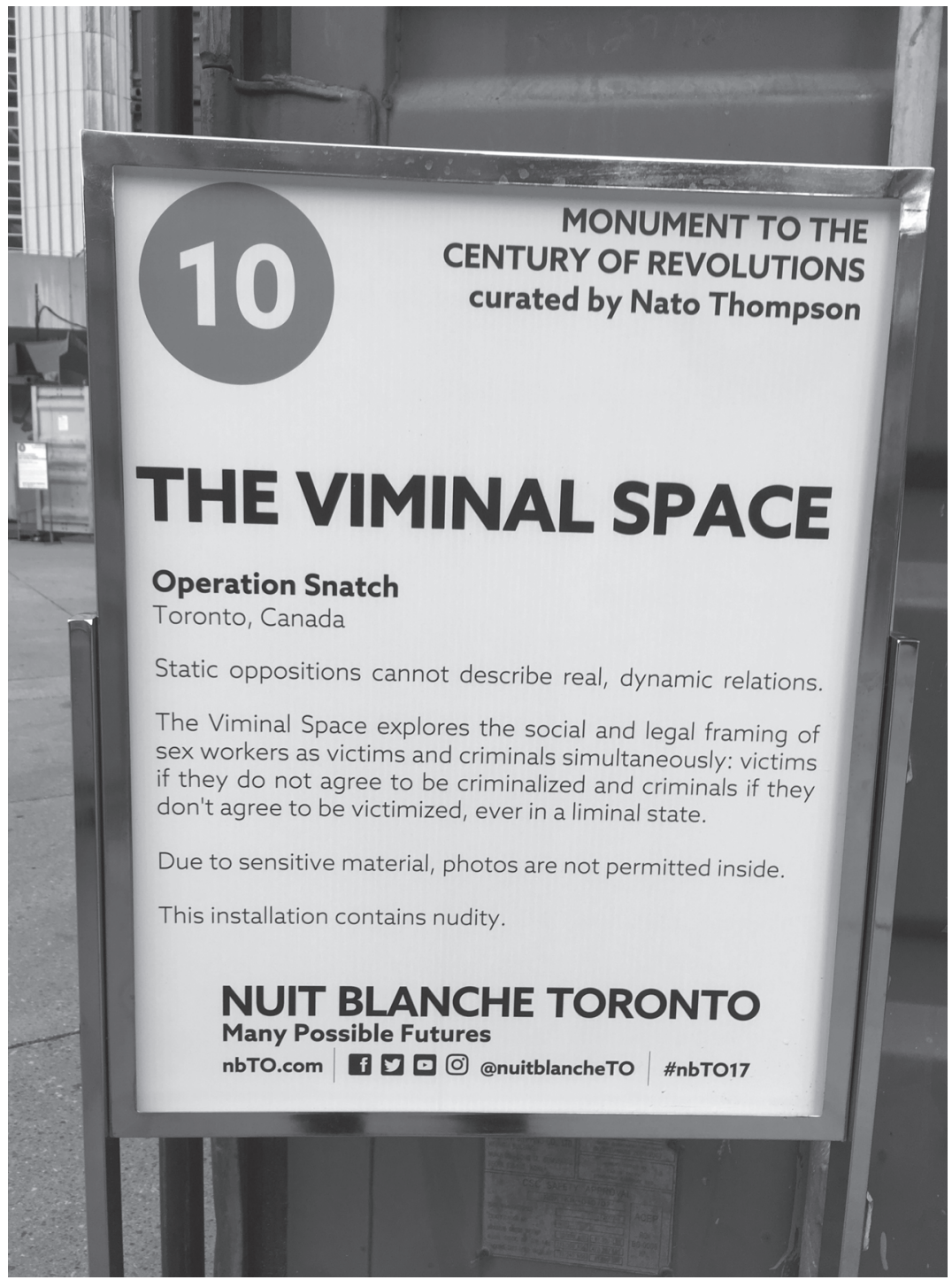

Image 1: The Viminal Space. Image credit: Alex Tigchelaar, 2017.

Stella community engagement is both creative and practical in nature. For example, a project called 'Je "C" Prends Soin de Moil' is a knapsack containing many useful items a Montreal street sex worker might need in their day-to-day work: gloves, socks, deodorant, baby wipes, nail clippers, moisturiser, and safer sex gear. It also includes vital information about Hepatitis $\mathrm{C}$ contraction. 


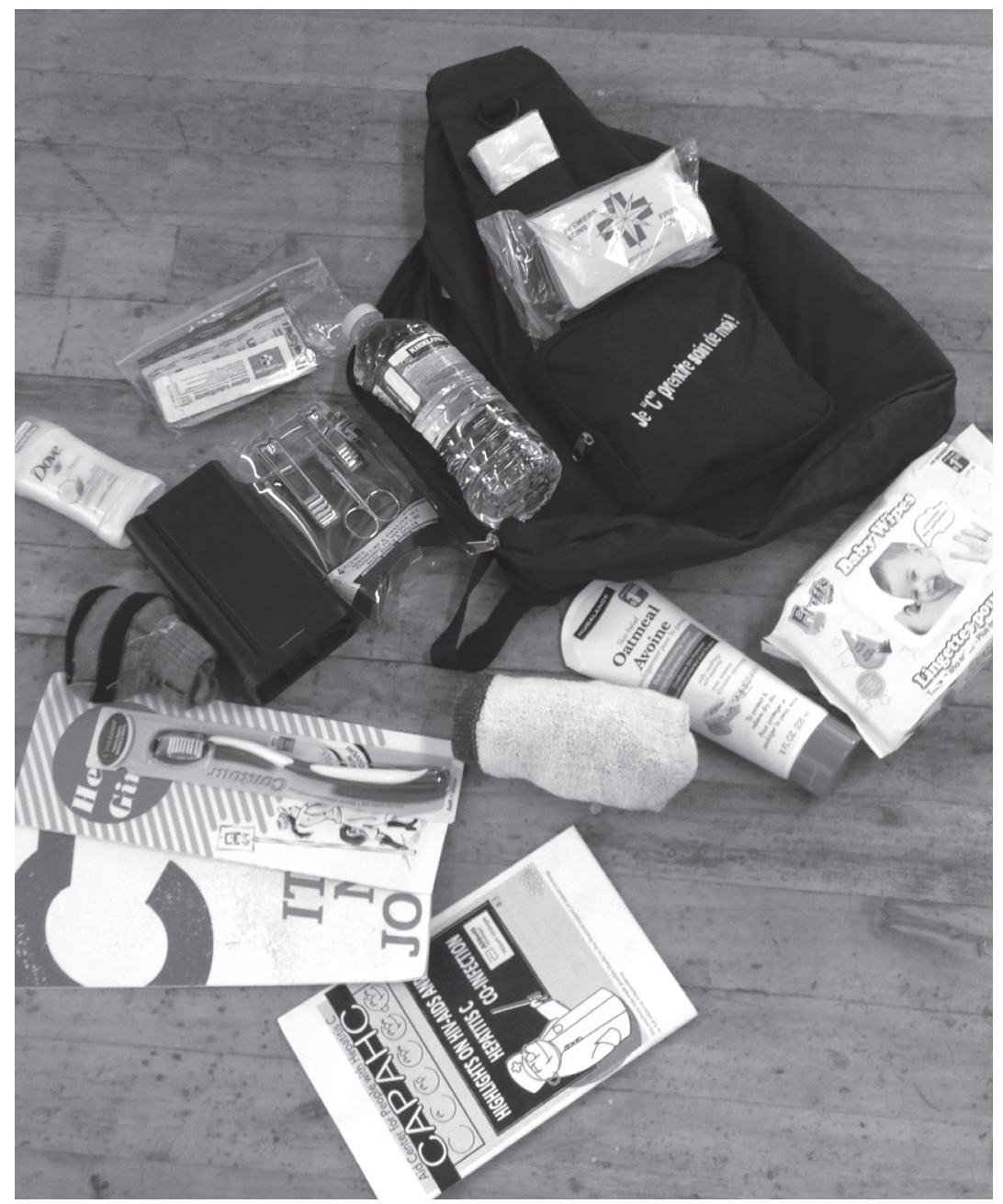

Image 2: Contents of Je "C" Prends Soin de Moi! Image credit: Alex Tigchelaar, 2015.

At its core, all of Stella's activist engagement recognises what sex workers need to work safely and comfortably, and the organisation supports them in this, be they working on the street, in massage parlours, for agencies, independently, or in strip clubs. Because of its long and highly imaginative record of outreach, Stella members were tasked with administering the 'sex work library' for The Viminal Space. They would be the 'Stellibrarians' and would give a visual and literary account of their twenty-two years of history, service, and activism. 
SWOP Behind Bars was launched in April 2016 and offers services to sex workers who are imprisoned in the United States. Though many North American groups do prison outreach, SWOP Behind Bars does this exclusively, supplying 'a monthly newsletter, books, study materials, and sex worker pen pals for incarcerated sex workers. ${ }^{19}$ SWOP Behind Bars is also present when sex workers are released from prison. Executive director Alex Andrews is a previously incarcerated sex worker and her experience in the criminal justice system is invaluable to the smooth functioning of this support network. For example, when sending books to incarcerated American workers, SWOP Behind Bars advises them to remove dust jackets and personally distinguishing information, to be cautious about signing the book if they are the author because it may be perceived as more valuable and denied shelving in the library, and to make sure there is nothing written in it that could be perceived as a secret code. The well-intentioned citizen seeking outreach opportunities with marginalised communities may have little experience with such circumscribing rules. As SWOP Behind Bars states, whether or not sex work is 'a symptom of poor economic conditions or volition it is always considered inherently immoral. ${ }^{20}$ This stigmatising qualification leaves many sex workers in a continuous state of penality: as designated sex offenders in the United States, when they are released, post incarceration housing and labour choices are limited, obliging many to go back into sex work, which in turn recriminalises them.

For The Viminal Space, SWOP Behind Bars members proposed a letter writing campaign to incarcerated sex workers in the United States. They would set up a table with paper, pens, and postage, and have the details of imprisoned workers, who had requested pen pals, ${ }^{21}$ available to people so that they could choose to whom they would like to write. This face-to-face engagement with members of the organisation would also be helpful in generating more general discussions about incarceration, and would draw attention to the conditions of the most frequently imprisoned sex workers in the United States: those who are negatively racialised and transgender.

The Sex Work Advisory Network of Sudbury (SWANS) is a programme that began in 2012. SWANS provides outreach to sex workers in this northern Ontario city, many of whom are Indigenous and street-involved. SWANS partnered with its local community arts group, Myths and Mirrors, to create

19 SWOP Behind Bars, website: http://swopbehindbars.org

20 Ibid.

21 In the United States, prisoners' personal details are widely available to the general public on the Internet, paradoxically making SWOP Behind Bars' outreach work easier than it would be in Canada, where details are not digitally disseminated. 
Project ArmHer, a collective of women with lived experience in sex work, and their allies. Project ArmHer encourages sex workers to join creativity workshops and positions them directly as actors, artists, and writers. The group proposed bringing three short films they had created, followed by monologues performed by participants, as well as a wearable installation piece-a metal breastplate embossed by members of their community with words of empowerment. Also featured were their Body Maps-life-size outlines of their physical geographies in chosen positions painted by the workers themselves. Project ArmHer uses Indigenous methodologies in their work, linking body violence to land violence, and every aspect of working with them involved a slow process of complete consensus, with every member of the group having a say in what would be produced and how. This was a poignant reminder about consent in our communities and how it is often abused by those hired to 'serve and protect'. Offerings by Project ArmHer such as the film Land of $M y$ Body ${ }^{22}$ reveal the coercive and silencing relationships of spatial and colonial power: 'The assault that took place in the back of the police cruiser tells another story. It whispers to me when I'm about to call the police-don't. ${ }^{93}$

We would present all of this work in an enclosed space that was eight by twenty feet (approx. 2,50 by 6 metres) for twelve straight hours. Many of us had not yet met in person. We were excited for this opportunity to network and support each other, but also had no idea what the night would bring.

\section{What Can Sex Workers Teach Us about Neoliberalism and the Creative City?}

When I use the term neoliberalism, I am referring specifically to definitions offered by David Harvey. He describes it as:

'a theory of political economic practices that proposes that human well-being can best be advanced by liberating individual entrepreneurial freedoms and skills within an institutional framework characterized by strong private property rights, free markets, and free trade. ${ }^{24}$

22 This short film contains an excerpt from Land of My Body by Sarah Gartshore. Gartshore is a playwright who has worked intimately with the group. She wrote the script through experiential sharing with the group.

${ }^{23}$ Land of My Body, Dir. by SWANS, Perf, SWANS, 2016.

${ }^{24}$ D Harvey, A Brief History of Neoliberalism, Oxford University Press, Oxford, 2005, p. 2. 
The role of the state in this economic model is to ensure the quality and reliability of its currency, 'to create and preserve an institutional practice for such models', ${ }^{25}$ and to provide the appropriate military, legal practices, and police force to support this model. Neoliberalism views the individual through their economic viability, and places this viability in the hands of the individual, with little consideration for existing privileges and sociopolitical access.

When I use the term 'the creative city', I am referring to neoliberal constructs of metropolitan revitalisation forwarded by the urban studies theorist Richard Florida. His theories promote attracting populations involved in technology, arts, and culture as a means of developing a city's appeal and by extension its economic power. Florida refers to the harbingers of this development model as 'the creative class.' Unsurprisingly, he never identifies sex workers as a vital segment of these populations, ${ }^{26}$ despite the fact that a noticeable percentage of the 'creative class' does sex work concurrent to their art and cultural practices, and despite the fact that sex workers' lives are frequently mined for creative potential by many members of this class. The harmful impact this has on sex working populations warrants critique; indeed, after fifteen years of implementing the creative city model on a global scale, Florida has himself declared his theories problematic, though primarily to the uncreative populations that end up servicing his creative class. ${ }^{27}$ To sex workers, the spatial and social violence entrenched in Florida's theories could not have been more obvious from the outset; the reality of what happens to them when their established workspaces (be they indoors or outdoors) become 'creatively classed' means nothing less than institutionalised forms of social expulsion. Sex workers know what happens when neighbourhoods become defined as 'good': the 'bad' populations are identified and targeted for removal. They know that 'safety' for the gentrifiers means danger to them. ${ }^{28}$

25 Ibid.

26 In Temporarily Yours: Intimacy, authenticity and the commerce of sex (University of Chicago Press, Chicago, 2007) Elizabeth Bernstein argues that 'the expanded presence of the white middle classes in gentrifying urban centers as both residents and tourists' (p. 4) has made street-based sex work less welcome while paradoxically drawing members of these classes-including Florida's creative class-to less visible and by extension safer indoor sex work. Over the past decade, enhanced digital surveillance of all categories of sex work has merged issues faced by all groups.

${ }^{27}$ R Florida, The New Urban Crisis, Basic Books, New York, 2017.

28 S Schulman, The Gentrification of the Mind, University of California Press, Berkeley, 2012. 
As Alison Bain argues, 'The metaphor of the creative city is supposedly an effort to think about cities differently and to develop a framework for problem solving'. ${ }^{29}$ In its peak form, 'the creative city would foster urban innovation and self-reliance through interdisciplinary and holistic thinking and partnerships based on inclusivity, accountability, and justice'. ${ }^{30}$ Resolutions would not be formulaic. They would be imaginative and daring. The problem is, in a neoliberal economic system where communities and individuals alike are evaluated based on their ability to advance financial productivity, individualistic meritocracy is gloried but rarely investigated through a critical intersectional lens. Answers have already been established through a premeditated system of appraisal that favours a positive financial outcome. The market decides if the idea is daring or creative.

In the spirit of thinking differently and problem solving in the neoliberal urban context, I propose an awareness and application of the creative city from a sex worker perspective. I contend that it is one that is socially progressive, risk-taking, and daringly original. Yet, because it exists in a state of 'viminality', it also troubles much radical critique of neoliberalist cultural production and the paradigm of 'artrepreneur.' As Jen Harvie argues, the mobilisation of artists as resourceful and independent 'artrepreneurs' is not entirely inaccurate. It defines, in positive terms, many qualities that 'are socially valuable and highly desirable, not least because they are expedient, helping artists to survive and sometimes thrive even while formerly semi-stable sources of public support for arts practices erode. ${ }^{31}$

The issue is not the description, rather the application; the expectations pinned on artists to show entrepreneurial pluck, "both indulge and inherently celebrate neoliberal capitalism. ${ }^{32}$ These expectations are ones also faced by sex workers and sex work activists. We, too, are required 'to model entrepreneurialism and to prioritize its values' in ways that gives precedence to 'self-interest individualism. ${ }^{33}$ In effect, we must: the only way that sex workers may work without criminalisation under PCEPA is through self-interest and individualism.

As a result of restrictive spatial and labour laws, sex workers are required to become intrepid and individualistic architects and users of the built environment. Applying Harvie's critical analysis of the hierarchy of pop-ups,

29 A Bain, "Creativ* suburbs: Cultural "popcorn" pioneering in multi-purpose spaces' in T Edensor, D Leslie, S Millington and N M Rantisi (eds.), Spaces of Vernacular Creativity: Rethinking the cultural economy, Routledge, New York, 2009, p. 64.

${ }^{30}$ Ibid.

31 Harvie, p. 62.

32 Ibid., pp. 62-63.

33 Ibid. 
I suggest that they are pop-up producers of the squatter variety. Pop-ups are short-term boutiques or galleries that take advantage of an empty retail space for a short-lived period of time so that pop-up producers do not have to worry about the financial burden of a long-term rental contract. Pop-ups may be licensed or informal, yet their sudden popularity over the past decade suggests spatial precarity that many new business owners face in neoliberal economies - the very same spatial precarity that criminalised sex workers have dealt with for centuries. Like squatters, and unlike licensed pop-up producers, when sex workers acquire space to live and work, 'however peacefully [...] they risk being criminalised by legislation which is increasingly intolerant of such interstitial, often highly beneficial uses of space. ${ }^{34}$ Sex workers produce workspaces in the urban setting that reveal proscription-based considerations: Will there be a private entrance so that clients may slip in undetected by neighbours? Will there be parking so that clients may park quickly and discreetly? They are also intensely creative: Does the ceiling need to be retrofitted for suspension play rigging? Should soundproofing be installed and how can it be made to look pleasing? What kind of erotic intention will the space reflect? All of these considerations must be carefully measured, while in Canada, the worker must also be prepared for the possibility that she may be ejected from this well-crafted space at any time, even if she is diligently paying rent or a mortgage $\mathrm{e}^{35}$ and even if she qualifies, as so many sex workers do, as successful under neoliberal pecuniary standards.

Depending on the type of trade she does, a sex worker may also be able to tell you what public or restaurant washrooms in the area are available to those known to be sex workers, ${ }^{36}$ what hotels have elevators that do not require key card entrance, and where one might find drop-in centres that offer safer sex gear and safer using kits. ${ }^{37}$ All of this is done under the reproving scrutiny of the more Floridian assemblage of the creative class, one that may enthusiastically consume media and art about sex work, but pushes sex workers out of long-established work locations because they are deemed a nuisance. Sex workers must always think differently and problem solve when it comes to the built environment, again, in many cases, because of gentrifying creative city initiatives that reproduce sentiments of entitlement to the urban (but not too urban, which in Canada is code for too many negatively racialised and/or street-involved populations) living experience. Parkdale, Toronto, long home

${ }^{34}$ Ibid., p. 126.

35 If, for example, she leases or owns this space and rents it to other workers to help cover bills and provide a safe and cooperative working environment.

36 This identification often leads to sex workers being banned from these locations.

37 Tigchelaar, 2014. 
to self-supporting communities of sex workers, ${ }^{38}$ continues to experience 'tensions between home-owners trying to shut down social services and the needs of new immigrants, sex trade workers, methadone clinic users, and various low-income residents. ${ }^{39}$

These disjunctures are perfect examples of the viminal space: sex workers may be able to check many boxes to qualify as 'artepreneurs' and they may even score high on Florida's absurdly named Bohemian Index. ${ }^{40}$ As gritty emblems of the urban environment, they are frequently exploited by cultural producers ${ }^{41}$ in multiple spaces of creation. Yet, simultaneously, they themselves are deliberately excluded from what is understood to be a more productive use of the urban space. Even if we view sex workers through Harvie's more generous reading of 'artrepreneur' discussed above, we may understand this designation is pertinent yet problematic. Harvie argues, "that because the "artrepreneur" works privately for her own advantage, she models neoliberalism' which "privileges the "liberty" of individuals to trade as they please and, in so doing, promotes private enterprise within apparently "free" or "open" markets over publicly regulated economies. ${ }^{42}$

When applied to sex working populations, it is evident that central to the case for decriminalisation is the right for sex workers to 'trade as they please.' Additionally, publicly regulated sex work economies often involve mandatory

38 The very same ones who produced, for example, the award-winning short film Prowling by Night in 1990, a harbinger for the ongoing police violence and NIMBYism towards sex workers that continues in Parkdale to this day. Prowling by Night. (1990). Dir. Gwendolyn. Dis. ONF/NFB. Film.

39 H McLean, 'The Politics of Creative Performance in Public Space: Towards a critical geography of Toronto case studies' in Spaces of Vernacular Creativity, p. 204.

40 R Florida, 'Bohemia and Economic Geography', Journal of Economic Geography, vol. 2, issue 1, 2002, pp. 55-71, https://doi.org/10.1093/jeg/2.1.55.

${ }^{41}$ Mammalian Diving Reflex's Diplomatic Immunities: The End (2007), is a theatre piece that 'offers a glimpse of Torontopia's engagement with truly grassroots street culture' in preparation for which 'Mammalian Diving Reflex performers interviewed a sex worker from the Bloor and Lansdowne area in west end Toronto.' Levin and Solga argue that this process turned interviewers 'into cultural tourists and the sex worker in their crosshairs into a piece of ethnographic research they could then handily transport home to their audiences' and that this sex worker 'was a prop, not a player, in Mammalian Diving Reflex's self-edifying excursion into the urban outlands'. See: L Levin and K Solga, 'Building Utopia: Performance and the fantasy of urban renewal in contemporary Toronto', TDR: The Drama Review, vol. 53, no. 3, 2009, p. 47, https://doi.org/10.1162/dram. 2009.53.3.37.

42 Harvie, p. 63. 
STI testing. ${ }^{43}$ With widespread policies criminalising sex-based HIV/AIDS exposure in Canada, this creates proscriptive working opportunities, forcing sex workers into outlawed versions of their labour or risk being imprisoned for not revealing their HIV status. ${ }^{44}$ Thus, defining these activities as harmfully modelling neoliberalism is problematic for these populations, ones who are criminalised for working together to enhance security, while at the same time being framed as a danger to the greater community and impeded from circulating freely amongst it. ${ }^{45}$ Moreover, it is often their financial success, the touchstone of neoliberalist accomplishment, that draws some of the most intense ire. Their bodies, 'one of the most significant resources determining an individual's performance in the market', ${ }^{46}$ are prevented from flourishing in this market, despite the fact that their labour patterns adhere to it flawlessly.

Neoliberalism, as Julie A. Wilson demonstrates, promotes a negative atmosphere of living in individualistic competition with others. ${ }^{47}$ This critique resonates differently with people who are required to individualise because of laws that prevent them from working and organising with others. The manner in which we, as sex workers, might address the issue of state-imposed selfenclosure could provide new critiques of and reflections on neoliberalism and urban spatial exclusion, ones that respect our views and experiences rather than occluding them. As Shawna Ferris argues, while 'post-industrial capitalism's utter devotion to the free market creates a potentially emancipatory

${ }^{43}$ E Jeffreys, J Fawkes and Z Stardust, 'Mandatory Testing for HIV and Sexually Transmissible Infections among Sex Workers in Australia: A barrier to HIV and STI prevention', World Journal of AIDS, no. 2, 2012, pp. 203-211, https:// doi.org/10.4236/wja.2012.23026.

44 'Due to no longer being regarded as a person who is protected under legal regimes, people who live in a negative relation to the law are under threat, they are overpoliced and under-protected, surveilled in their communities, and they live in a context where information about them is collected, exposed, dispersed and mobilized to incapacitate their bodies and circumscribe their life chances and opportunities.' See: A McClelland, “Lock this Whore up": Information converging to circumscribe and incapacitate threats to public safety in the Canadian context of HIV criminalisation', European Journal of Risk Regulation, forthcoming, 2019, pp. $1-17$, p. 2.

45 McClelland argues that, "When a person is marked as a criminal and a threat to public safety, a wide range of information is produced and proliferates about the person and their case, such as press releases, legal case documents, media articles and interviews, personal photographs, institutional directives, expert opinions, medical files, social media and bulletin board posts, police communications and interviews.' Ibid., p. 1.

46 S Hoffman, 'Tracing Contradictions of Neoliberal Governmentality in Tijuana's Sex Trade', Anthropology Matters, vol. 15, no. 1, 2014, pp. 63-90, p. 66.

${ }^{47} \mathrm{~J}$ A Wilson, Neoliberalism, Routledge, New York and London, 2018. 
space for sex workers as producers, consumers, and investors in a deregulated consumer culture', with 'increasing calls for law and order and social control, this political space becomes dangerously fraught. ${ }^{38}$ Sex workers can teach average citizens a lot about community-building and economic endurance in neoliberalist models of self-enclosure and individualism. We have been forced to live, work, and organise under analogous paradigms for centuries.

\section{Reframing Nuit Blanche as Nuit Business}

I would argue that it is disingenuous, given the overwhelming amount of critical analysis available not just to scholars, but to activists and to the general public, to imagine that large scale public arts events like Nuit Blanche will unfailingly stand behind the ambitious, overarching vision of their theme, and abidingly support the communities they involve in it. Therefore, it was of little surprise to me that, during email exchanges closing in on the event, the organisers of Nuit Blanche requested that we not have the word 'sex' on our shipping container. This meant that the banners virtually every sex worker rights organisation has for demonstrations would not be permitted to hang on our container. No reasonable motive was given for this restriction, but as a sex worker, I am accustomed to this type of mutable policymaking. After all, the very laws that govern our actions in this country name us as 'exploited' regardless of how we personally identify. I made it clear to the organisers that, because of intense and repressive marginalisation, our banners often represented us. However, I was not ready to fight tooth and nail to have those with the word 'sex' on our container. I had already been looking at the creative aspects of our container with an eye to advantageous civilian engagement and potential funding-by-associative-prestige for the organisations. Henceforth, I truly began approaching Nuit Blanche as if it were an industry conference and I applied industry conference standards to my curatorial practice.

Conference goers, for example, can anticipate leaving with items that include business addresses and slogans on them, such a pens, key-chains, and miniflashlights. These are designed as reminders of the businesses' objectives and services and are easy to pocket. We decided our best takeaway would be a tool of our trade-condoms - and that we would put messages on them about criminalisation that would generate thoughtful conversation. We made two, one that read, 'Using condoms as evidence of prostitution is a widespread police practice', and another that read, 'Condom use negotiation between sex workers and clients is a criminal act in Canada. Decriminalize sex work!' These messages made clear one of the day-to-day stresses of living in The Viminal Space.

${ }^{48}$ S Ferris, Street Sex Work and Canadian Cities: Resisting a dangerous order, University of Alberta Press, Edmonton, 2015, p. 3. 


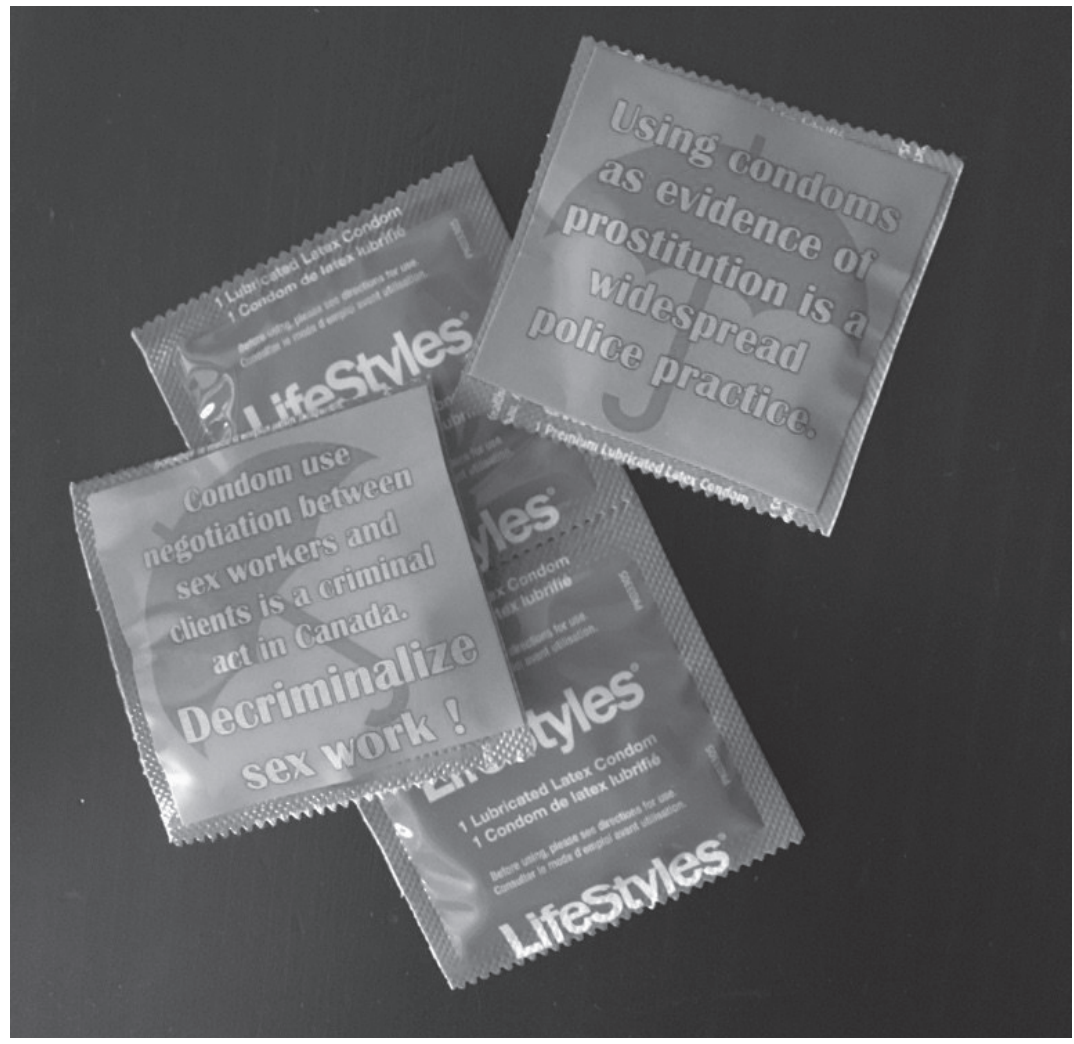

Image 3: Condoms as Evidence. Image credit: Stella member, 2017.

\section{Revolution is Not a Safe Space}

When I arrived on location at Nathan Phillips Square in Toronto, I immediately noticed three long banners hung on three stacked shipping containers that had been painted by a member of Chto Delat. These banners read, 'Revolution is Not a Safe Space.' This declaration brought to the fore the polarising and easily satirised arguments so many of us have been privy to in North American sex working communities about what qualifies as safe space, who is responsible for keeping the security operational, and what safety demands qualify as critical. The divide is as distinctly generational as it is in academic and queer communities. ${ }^{49}$ Why should youth care that their elders were being shoved

49 See: J Halbertstam, 'You Are Triggering me! The neo-liberal rhetoric of harm, danger and trauma', Bully Bloggers, 5 July 2014, retrieved 23 December 2018, https://bullybloggers.wordpress.com/2014/07/05/you-are-triggering-me-theneo-liberal-rhetoric-of-harm-danger-and-trauma. 


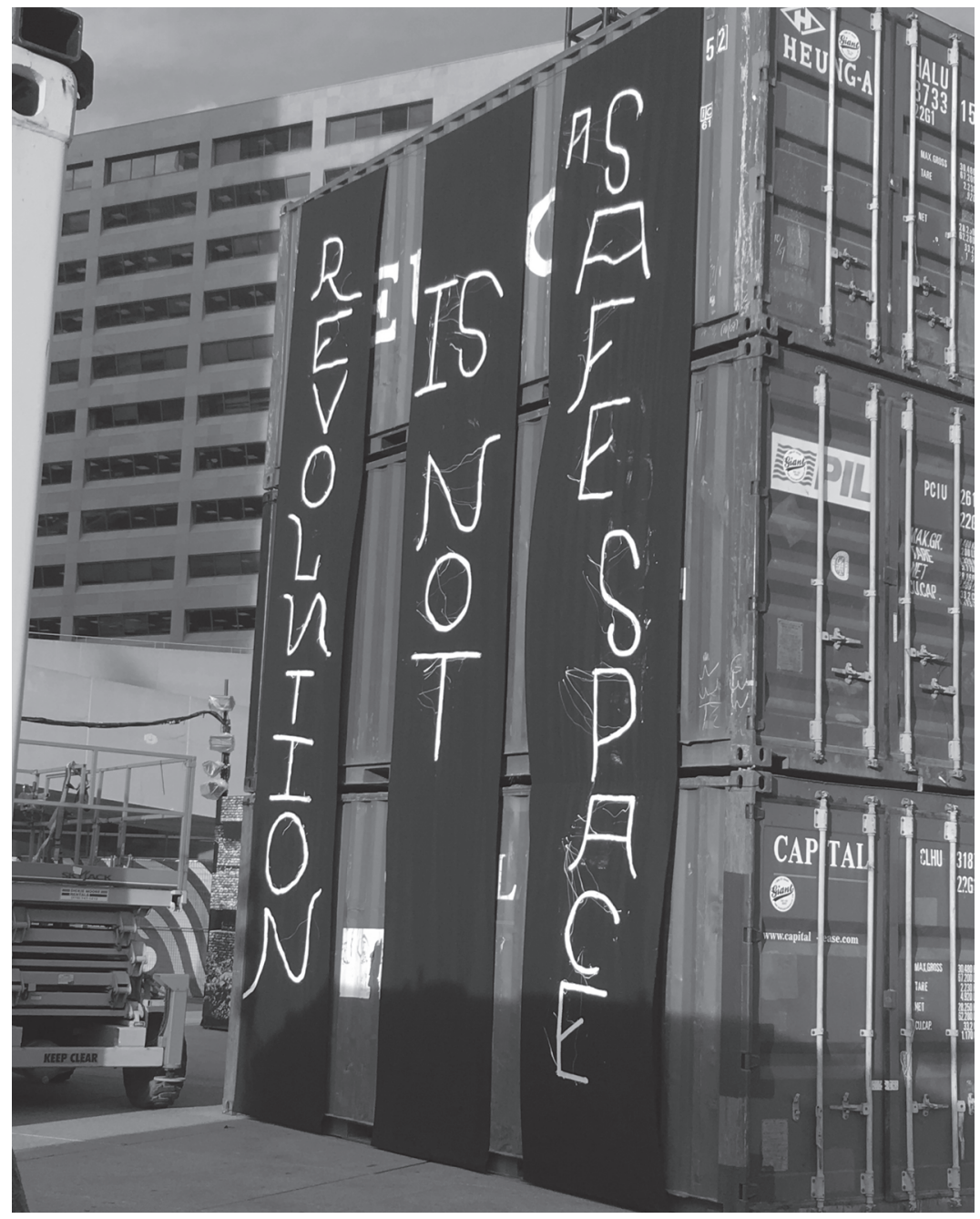

Image: 4 Revolution is not a Safe Space. Image credit: Alex Tigchelaar, 2017.

into police cars before they were born? And why should elders care that youth are being devoured by unpaid digital labour? Because revolution is not a safe space, we need to acknowledge that the fear that occupies this space often disguises itself as antagonistic bravado.

This 'space acknowledgment' felt especially meaningful from a group that knows all too well how risky public activism can be. In Russia, groups of grassroots activists are prevented from taking over public space since individual 
protest is the only possible form of legal unauthorised protest. Groups of Russian activists, like groups of sex workers, are legislatively constituted as a danger to public wellbeing and prevented from collaborating for their own safety. Yet, this does not stop them from protesting in ways that may compromise their safety and spatial mobility.

Wilson argues that those from 'historically oppressed and marginalized groups [...] suffer daily', living 'in an environment that professes to celebrate "diversity", while in the context of their own lives, they are reminded again and again just how much they don't belong or matter.' In the academic context, she argues that it is no surprise that these communities 'demand "safe spaces" and protection for themselves and their peers', often making strong divides 'between allies and enemies. ${ }^{50}$ This is something that all sex workers can understand. In public spaces, our safety is compromised by our mere presence. Work about our work is openly displayed in public space, occupying billboards and marquees without fear of recrimination. Creative work about sex work is normalised and consumed as such. Women who play sex workers in film, theatre, and television are often bestowed industry awards for their efforts. We, however, must be cautious when we present our own creative and activist work in public as our 'inclusion within the law as sex workers is simultaneously an act of exclusion. ${ }^{51}$ Openly identifying as a sex worker carries enormous stigma, and for those with tenuous migration status, the possibility of deportation. ${ }^{52}$ Active sex workers are also not permitted entry into the United States ${ }^{53}$ and, if they are identified as such, are banned from entering for periods extending from five to ten years. While being knowledgeable about and accountable to the risks of our direct engagement, it was also important to establish a very sex worker-specific version of safe space for our container. Written into our contract was a clause that there would be no photographs inside our container and that Nuit Blanche would not be permitted to document us in this space either. This request was a form of advocacy in itself. It made organisers aware that dealing with criminalised populations in highly visible spaces meant forgoing the kind of visual documentation that helps establish their events as worth attending, and, by extension, funding. We would be in control of the economic instrumentalisation and wellbeing of

${ }^{50}$ Wilson, 2018, p. 14.

51 G Pratt, 'Abandoned Women and Spaces of the Exception', Antipode, vol. 37, 2006, pp. 1052-1078, p. 1059, https://doi.org/10.1111/j.0066-4812.2005. 00556.x.

52 E Lam, 'Bill C-36's Negative Impact on Racialized and Migrant Sex Workers', Rabble, 26 November 2014, retrieved 8 December 2017, http:/ / rabble.ca/news/ 2014/11/bill-c-36s-negative-impact-on-racialized-and-migrant-sex-workers.

53 Maggie's, 'Safer Border Crossing Tips for Sex Workers', Maggie's, n.d., http:// maggiestoronto.ca/uploads/File/FINAL_USborderrights.htm. 
our bodies by revealing yet another way in which cultural representation 'is a process that hides the apparatus of domination from the dominant themselves. ${ }^{54}$

\section{Conclusion}

The Viminal Space had line-ups until the early morning. SWOP Behind Bars mailed 325 letters to incarcerated sex workers from participants. The performances by Project ArmHer were deeply appreciated and the group was so inspired by the response that they added an additional three to the night. The condoms made by Stella generated many fruitful conversations about the contradictions between criminalising sex workers for not providing safe experiences while simultaneously depriving them of the right to do so. These, in turn, generated conversations about the many ways in which sex workers are deprived of basic labour rights while so many others profit off their cultural cachet.

It was a challenging evening. Twelve hours in a packed shipping container from dusk to dawn on a cold autumn night is a long shift, though this was made much easier by the fact that a patron booked us a hotel room close to the venue so that we might rest and freshen up. Our clients often support our activism, but of course, they must do so with some degree of caution for fear of being identified and branded sex offenders, unlike the many cultural and economic institutions keen to broadcast their associations with the creative class. Making sure people did not photograph us required vigilance as so many people are accustomed to the privilege of unfettered visibility and the freedom to be seen without being criminalised. But challenge can be stimulating: the act of requesting people not take photos prompted conversations about privacy and taken-for-granted social and digital mobility.

Borrowing from cabaret theatre scholar'TL Cowan, McLean argues that, 'women artists can become entangled in exclusionary creative city initiatives by providing entrepreneurialized arts organisations with edgy feminist and queer artistic fare. ${ }^{55}$ But she also suggests that we can subvert these enterprises using tactics that challenge aggressive systems of privatisation, intolerant notions of citizenship, and colonisation. ${ }^{56}$

${ }^{54}$ Schulman, p. 27.

55 H McLean, 'Hos in the Garden: Staging and resisting neoliberal creativity', Society and Space, vol. 35, no. 1, 2017, pp. 38-56, p. 2, https://doi.org/10.1177/0263775 816654915.

56 Ibid. 
After our communities across Canada had suffered a demoralising loss with the ascent of PCEPA, our involvement in events that themselves have troubled histories of displacement and misrepresentation remains vexed. But recognising that events like Nuit Blanche can be activated as spaces of political and entrepreneurial opportunity is critical to our voices being heard. These events offer us direct access to populations who are often armed with conflicted messages around sex work and human trafficking. They provide us the ability to discuss how these contradictions often fuel entitlement to residential and public spaces that do not include real sex workers. Direct contact with our fellow citizens is essential for more politicised knowledge production around the real impacts of the criminalisation of sex work, of spatial violence, and the multiple impacts of the neoliberal creative city model on sex workers. As businesspersons with legitimate concerns about our access to and visibility in public space, both exploited by neoliberal cultural economies and left out of them concurrently, we can find ways to instrumentalise these events to our benefit. And of course, in the end, we simply put all our banners up, sex and everything. Revolution, after all, is not a safe space.
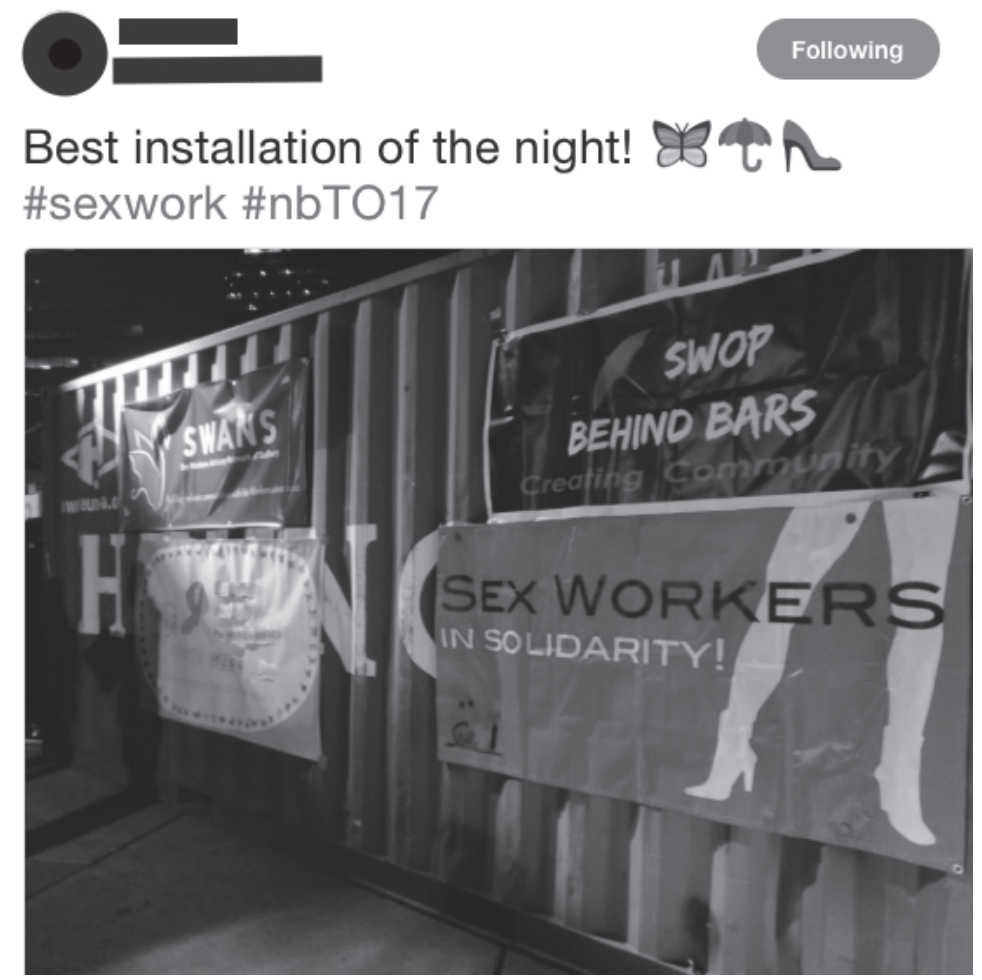

Image 5: Best Installation of the Night! Image credit: Selene S, 2017. Used with permission from her Twitter feed. 
I would like to thank the technical and security staff of Toronto's Nuit Blanche 2017 for their excellent care and attention.

Alex Tigchelaar is the Research and Development Coordinator at the Institute for Urban Futures at Concordia University, Montreal, Canada. Since 2014 she has been a research assistant on the project Recounting Huronia, which pairs survivors of institutional violence from the Huronia Regional Centre with artists, activists and scholars to update the public record through speaking engagements and arts-based projects. Email: alexandrao. tigchelaar@mail.concordia.ca. 